\title{
Detection of Pseudomonas aeruginosa producing metallo- $\beta$-lactamase VIM-2 in a central hospital from Portugal
}

\author{
A. Pena - A. M. Donato • A. F. Alves • \\ R. Leitão • O. M. Cardoso
}

Received: 6 February 2008 / Accepted: 6 June 2008 / Published online: 16 July 2008

(C) Springer-Verlag 2008

Pseudomonas aeruginosa remains one of the most important pathogens in the nosocomial setting [1]. P. aeruginosa exhibits intrinsic resistance to several antimicrobial agents. The antipseudomonal $\beta$-lactams represent a major weapon against Pseudomonas infections, either for monotherapy or for combination therapy, for which $\beta$-lactams almost invariably represent one of the components. Therefore, resistance to these agents constitutes a major challenge for anti-Pseudomonas chemotherapy. Several mechanisms can contribute to $\beta$-lactam resistance in $P$. aeruginosa, including $\beta$-lactamase production, outer membrane impermeability and active efflux mediated by RND-type efflux systems [1]. During the last decade, the metallo- $\beta$-lactamases (MBLs) have emerged as new threatening mechanisms of broad-spectrum $\beta$-lactam resistance in $P$. aeruginosa. In fact, these enzymes can efficiently degrade virtually all antipseudomonal $\beta$-lactams (except aztreonam), while they are not susceptible to therapeutic $\beta$-lactamases inhibitors [2]. Based on amino acid sequence homology, these MBLs have been classified into four major types: IMP, VIM, SPM

A. Pena $\cdot$ R. Leitão $\cdot$ O. M. Cardoso $(\bowtie)$

Laboratory of Microbiology, Centro de Estudos Farmacêuticos, Faculty of Pharmacy, University of Coimbra,

Couraça dos Apostolos $51 \mathrm{r} / \mathrm{c}$ esq,

3000-432 Coimbra, Portugal

e-mail: ocardoso@ci.uc.pt

\section{A. M. Donato}

Laboratory of Clinical Analysis of the Faculty of Pharmacy, University of Coimbra,

Couraça dos Apostolos $51 \mathrm{r} / \mathrm{c}$ esq,

3000-432 Coimbra, Portugal

\section{A. F. Alves}

Laboratory of Microbiology, Centro Hospitalar de Coimbra, Quinta dos Vales, S. Martinho do Bispo,

3046-853 Coimbra, Portugal and GIM. Clinical isolates harbouring the MBLs IMP and VIM have been increasingly reported worldwide, mostly in European and Asian countries [2]. This increase in occurrence, types and rate of dissemination of MBLs makes early detection very critical. The benefits of such treatment include the timely implementation of strict infection control practices, as well as clinical guidance.

The aim of this study was to determine the presence of these enzymes in imipenem-resistant $P$. aeruginosa isolates collected at the Centro Hospitalar of Coimbra ( $\mathrm{CHC}$ ), during a two-year period (April 2003 to April 2005) and to ascertain their clonal relationship. $\mathrm{CHC}$ is a cluster formed by a central hospital and several specialised units located at distances of less than $8 \mathrm{~km}$, namely, Hospital dos Covões (central hospital), Instituto Maternal (maternity hospital) and Hospital Pediátrico (paediatric hospital). The Microbiology Laboratory also analysed samples from another hospital (Hospital de Pombal) located $30 \mathrm{~km}$ away.

Bacterial identification and minimal inhibitory concentrations (MIC) were performed with the MicroScan WalkAway (Dadebehring) system according to the instructions of the manufacturer and API32GN or API PSE systems (bioMérieux). All intermediate strains were considered as nonsusceptible strains. The MICs of $\beta$-lactams were also determined by E-test in isolates that presented the enzyme VIM-2. The results were interpreted on the basis of CLSI recommended breakpoints [3]. The screening of MBLs was done by the double combined disk test [4]. Polymerase chain reaction (PCR) analyses for the detection of MBLs genes (bla IMP $_{1}$ bla $a_{\mathrm{VIM}}$, bla $_{\mathrm{GIM}}$ and bla $\left._{\mathrm{SPM}-1}\right)$ were carried out for all strains in which the screening test gave positive results [5]. The amplicons were directly sequenced on both DNA strands on an ABI PRISM 377 automated sequencer. The nucleotide and deduced amino acid sequences were analysed with software available online (http://blast.ncbi.nlm.nih.gov/ 
Blast.cgi). VIM-2-producing isolates were typed by random amplified polymorphic DNA (RAPD) with primer 272 [5]. Samples with the same banding pattern were assigned a letter indicating a single RAPD type. Those with no more than one major band or three minor band differences were thought to be related and great differences in the banding patterns were considered to be a different pattern [5].

On the basis of resistance phenotype (resistance or intermediate susceptibility to imipenem), 134 isolates were selected and studied for MBL production. The susceptibility of these $P$. aeruginosa isolates relative to $\beta$-lactams antibiotics was: ceftazidime, $56.7 \%$; piperacillin plus tazobactam, 47.4\%, and aztreonam, 37.3\%. Meropenem still demonstrated some activity (20.3\%). Among these imipenem-resistant isolates, $3.7 \%$ were characterised by multidrug resistance, including all of the tested drugs. In our study, carbapenem resistance rates did not correlate with the presence of VIM-2, as $80.6 \%$ of the strains were resistant to imipenem without MBL production. This demonstrates that other resistance mechanisms were involved, such as permeability mutations via the loss of porins or the up-regulation of efflux systems [1].
The combined disk method was positive in 40 imipenemresistant isolates, but by PCR, the presence of an amplicon of $815 \mathrm{pb}$ in size (detection of bla $a_{\mathrm{VIM}}$ ) was observed in only 26 isolates. No amplification was observed with $b l a_{\mathrm{IMP}}, b l a_{\mathrm{SPM}}$ and $b l a_{\mathrm{GIM}}$ primers. DNA sequencing of the amplicons confirmed that these 26 isolates harboured $b l a_{\mathrm{VIM}-2}$. MBL-producing gram-negative organisms have now been reported in many geographic regions [2]. The MBL found in our hospital is VIM-2, which is scattered in several European countries, namely, France, Italy and Greece [2]. The $b l a_{\mathrm{VIM}}$-positive isolates were detected during the time of the study and appeared to be widely distributed in the central hospital, and even outside of it. bla $_{\mathrm{VIM}}$-positive $P$. aeruginosa represented $19.4 \%$ of the carbapenem-resistant $P$. aeruginosa isolates. These numbers are lower than those reported for MBL producers from a SENTRY Antimicrobial Surveillance Programme [6], but exceed other reports from Italy [7]. Among these isolates, VIM-2 producers' MICs were determined by E-test and the results are presented in Table 1. Resistance to all of the tested drugs was observed in $15.4 \%$ of these isolates. Furthermore, the majority of the multidrug-resistant isolates

Table 1 Minimal inhibitory concentrations (MICs) of $\beta$-lactams of VIM-2-producing Pseudomonas aeruginosa and respective random amplified polymorphic DNA (RAPD) types

\begin{tabular}{|c|c|c|c|c|c|c|c|}
\hline \multirow[t]{2}{*}{ Isolate no. } & \multicolumn{5}{|c|}{ MIC (mg/L) } & \multirow[t]{2}{*}{ Ward/hospital } & \multirow[t]{2}{*}{ RAPD type } \\
\hline & IP & MP & CAZ & AZT & PIP & & \\
\hline $17735 / 03$ & $>32$ & 32 & 24 & 3 & 16 & Neurosurgery/Hosp. Covões & A \\
\hline $17872 / 03$ & $>32$ & $>32$ & 24 & 3 & 8 & Orthotraumatology/Hosp. Covões & A \\
\hline $14593 / 03$ & $>32$ & 32 & $>256$ & 16 & $>256$ & Reanimation/Hosp. Covões & $\mathrm{A}$ \\
\hline $17000 / 03$ & $>32$ & $>32$ & 32 & 3 & 24 & Reanimation/Hosp. Covões & $\mathrm{A}$ \\
\hline $19210 / 03$ & $>32$ & $>32$ & 24 & 3 & 24 & Reanimation/Hosp. Covões & A \\
\hline $1891 / 04$ & $>32$ & $>32$ & 2 & 3 & 24 & Reanimation/Hosp. Covões & A \\
\hline $12321 / 04$ & $>32$ & $>32$ & 32 & 3 & 16 & Reanimation/Hosp. Covões & A \\
\hline $18441 / 03$ & $>32$ & 6 & 16 & 2 & 16 & Medicine/Hosp. Covões & A \\
\hline $712 / 04$ & $>32$ & $>32$ & 24 & 3 & 16 & Medicine/Hosp. Covões & A \\
\hline $1825 / 04$ & $>32$ & $>32$ & 32 & 256 & 32 & Medicine/Hosp. Covões & A \\
\hline $3647 / 04$ & $>32$ & $>32$ & 32 & 2 & 16 & Medicine/Hosp. Covões & $\mathrm{A}$ \\
\hline $4584 / 04$ & $>32$ & $>32$ & 32 & 2 & 24 & Medicine/Hosp. Covões & $\mathrm{A}$ \\
\hline $6741 / 04$ & $>32$ & $>32$ & 24 & 16 & 24 & Medicine/Hosp. Covões & $\mathrm{A}$ \\
\hline $1801 / 04$ & $>32$ & 4 & 32 & 2 & 16 & Pneumology/Hosp. Covões & A \\
\hline $14349 / 04$ & $>32$ & 3 & 16 & 2 & 12 & Pneumology/Hosp. Covões & A \\
\hline $21800 / 04$ & $>32$ & $>32$ & 32 & 4 & 16 & Pneumology/Hosp. Covões & A \\
\hline $429 / 05$ & $>32$ & $>32$ & 32 & 6 & 32 & Pneumology/Hosp. Covões & A \\
\hline $17053 / 04$ & $>32$ & 8 & 32 & 1,5 & 32 & Reanimation/Hosp. Covões & A1 \\
\hline $541 / 05$ & $>32$ & $>32$ & 16 & 3 & 32 & Pneumology/Hosp. Covões & A1 \\
\hline $15153 / 04$ & $>32$ & $>32$ & 32 & $>256$ & $>256$ & Medicine/Hosp. Pombal & $\mathrm{B}$ \\
\hline $18769 / 04$ & $>32$ & $>32$ & 24 & 64 & $>256$ & Medicine/Hosp. Pombal & $\mathrm{B}$ \\
\hline $5783 / 03$ & $>32$ & 3 & 24 & 1 & 48 & Infectious/Hosp. Covões & $\mathrm{C}$ \\
\hline $11874 / 04$ & $>32$ & $>32$ & $>256$ & 96 & $>256$ & Infectious/Hosp. Covões & $\mathrm{D}$ \\
\hline $17083 / 03$ & $>32$ & $>32$ & 64 & 3 & 48 & Infectious/Hosp. Covões & $\mathrm{D}$ \\
\hline $7147 / 03$ & $>32$ & 4 & 2.5 & 3 & 4 & Medicine/Hosp. Paediatric & $\mathrm{E}$ \\
\hline $19168 / 03$ & $>32$ & $>32$ & 64 & 2 & 16 & UIC/Hosp. Paediatric & $\mathrm{F}$ \\
\hline
\end{tabular}

$\mathrm{IP}=$ imipenem; $\mathrm{MP}=$ meropenem; $\mathrm{CAZ}=$ ceftazidime; $\mathrm{AZT}=$ aztreonam; $\mathrm{PIP}=$ piperacillin 
were producers of VIM-2, which agrees with other studies carried out in Italy that described 76\% VIM-2-producing $P$. aeruginosa clinical isolates with resistant phenotype [8].

In this work, $P$. aeruginosa isolates that produce VIM-2 were detected in six different wards of Hospital dos Covões and in another two geographically distinct hospitals (Hospital Pediátrico and Hospital de Pombal). Six genotypically different strains were identified (Table 1). Pattern A comprised 17 isolates $(65.4 \%)$ that were disseminated in five wards of the central hospital. Subpattern A1 was constituted of two isolates closely related to pattern A, suggesting that a small mutation occurred in isolate A, creating the former pattern. These results demonstrated that we had the same strain harbouring VIM-2 disseminated in various wards of the central hospital. This reality was different from another study carried out in Greece where the VIM-2 isolates were unrelated [9]. Pattern B represented two isolates of Hospital de Pombal, a geographically distinct hospital. In the Infectious ward, two samples of $P$. aeruginosa with identical patterns classified as $\mathrm{D}$ and another isolate classified as pattern $\mathrm{C}$ were isolated. This diversity suggested the spread of the $b l a_{\mathrm{VIM}-2}$ gene among genetically distinct $P$. aeruginosa strains $[9,10]$. In this ward, clone A was not found, suggesting that the prevention measures and control of the spread of pathogen are more effective in this ward. The remaining two isolates were identified as patterns $\mathrm{E}$ and $\mathrm{F}$, respectively, and were recovered from the Medicine ward and the Unit of Intensive Care of Paediatric Hospital, another geographically distinct hospital.

In our study, MBL-positive strains had a common multidrug-resistant phenotype that not only included carbapenems, but also last-generation cephalosporins, aminoglycosides and fluoroquinolones. The possibility that spreading transferable MBL genes among nosocomial gram-negative pathogens could emerge as a major problem in the clinical setting reinforces the need for the systematic surveillance of these resistance determinants. The early detection of MBL-carrying organisms is of paramount clinical importance, as it allows the rapid initiation of strict infection control practices, as well as the selection of appropriate antimicrobial agents.
Acknowledgements We thank FCT through POCTI (FEDER) for financial support.

The authors thank Trindade Marques and Jorge Marques for their assistance with the data management.

\section{References}

1. Rossolini G, Mantengoli E (2005) Treatment and control of severe infections caused by multiresistant Pseudomonas aeruginosa. Clin Microbiol Infect 11(Suppl 4):17-32 doi:10.1111/j.14690691.2005.01161.x

2. Walsh TR, Toleman MA, Poirel L, Nordmann P (2005) Metallo$\beta$-lactamases: the quiet before the storm? Clin Microbiol Rev 18:306-325 doi:10.1128/CMR.18.2.306-325.2005

3. Clinical and Laboratory Standards Institute (CLSI) (2005) Performance standards for antimicrobial susceptibility testing: 15th informational supplement, vol. 25. CLSI, Wayne, PA

4. Yong D, Lee K, Yum JH, Shin HB, Rossolini GM, Chong Y (2002) Imipenem-EDTA disk method for differentiation of metallo- $\beta$-lactamase-producing clinical isolates of Pseudomonas spp. and Acinetobacter spp. J Clin Microbiol 40:3798-3801 doi:10.1128/JCM.40.10.3798-3801.2002

5. Cardoso O, Alves AF, Leitão R (2008) Metallo- $\beta$-lactamase VIM2 in Pseudomonas aeruginosa isolates from a cystic fibrosis patient. Int $J$ Antimicrob Agents 31:375-379 doi:10.1016/j. ijantimicag.2007.12.006

6. Toleman MA, Biedenbach D, Bennett DMC, Jones RN, Walsh TR (2005) Italian metallo- $\beta$-lactamases: a national problem? Report from the SENTRY Antimicrobial Surveillance Programme. J Antimicrob Chemother 55:61-70 doi:10.1093/jac/dkh512

7. Luzzaro F, Endimiani A, Docquier J-D, Mugnaioli C, Bonsignori M, Amicosante G, Rossolini GM, Toniolo A (2004) Prevalence and characterization of metallo- $\beta$-lactamases in clinical isolates of Pseudomonas aeruginosa. Diagn Microbiol Infect Dis 48:131135 doi:10.1016/j.diagmicrobio.2003.09.005

8. Lagatolla C, Tonin EA, Monti-Bragadin C, Dolzani L, Gombac F, Bearzi C, Edalucci E, Gionechetti F, Rossolini GM (2004) Endemic carbapenem-resistant Pseudomonas aeruginosa with acquired metallo- $\beta$-lactamase determinants in European hospital. Emerg Infect Dis 10:535-538

9. Pournaras S, Maniati M, Petinaki E, Tzouvelekis LS, Tsakris A, Legakis NJ, Maniatis AN (2003) Hospital outbreak of multiple clones of Pseudomonas aeruginosa carrying the unrelated metallo- $\beta$-lactamase gene variants $b l a_{\mathrm{VIM}-2}$ and $b l a_{\mathrm{VIM}-4}$. J Antimicrob Chemother 51:1409-1414 doi:10.1093/jac/dkg239

10. Lagatolla C, Edalucci E, Dolzani L, Riccio ML, De Luca F, Medessi E, Rossolini GM, Tonin EA (2006) Molecular evolution of metallo- $\beta$-lactamase-producing Pseudomonas aeruginosa in a nosocomial setting of high-level endemicity. J Clin Microbiol 44:2348-2353 doi:10.1128/JCM.00258-06 